\title{
ОПЫТ ИСПОЛЬЗОВАНИЯ НИЗКИХ ДОЗ ЭСТРОГЕНА В ЛЕЧЕНИИ ДЕВОЧЕК С СИНДРОМОМ ШЕРЕШЕВСКОГО-ТЕРНЕРА В ДОПУБЕРТАТНОМ ПЕРИОДЕ ДЛЯ РОСТОВОГО ПРОГНОЗА
}

\author{
О.А. Дианов ${ }^{1,2}$, С.В. Шаламова ${ }^{2}$ \\ 1ГБУЗ Тверской области «Клиническая детская больница №2», г. Тверь \\ 2ФГБОУ ВО «Тверской государственный медицинский университет» Минздрава России, г. Тверь
}

АКтУАЛЬНОСТЬ: синдром Шерешевского-Тернера (СШТ) встречается с частотой 1:2000-1:2500 новорожденных девочек. В 95-100\% случаев у пациенток с СШТ наблюдается внутриутробная задержка роста, низкая скорость роста после 3 лет, отсутствие ростового скачка в пубертатном возрасте.

ЦЕЛЬ ИССЛЕДОВАНИЯ: сравнить эффективность комбинированной терапии рекомбинантным гормоном роста (рГР) (Растан) и низких доз эстрогена (Прогинова) с монотерапией рГР среди девочек с синдромом Шерешевского-Тернера в улучшении ростового прогноза.

МАТЕРИАЛЫ И МЕТОДЫ: в исследование были включены 14 пациенток с подтвержденным диагнозом СШТ. Исследуемые были разделены на 2 группы: 1-я группа - комбинированная терапия рГР с низкими дозами эстрогена $(n=7), 2-я$ группа - монотерапия рГР $(n=7)$. Эффективность терапии оценивалась на основании изменения коэффициента стандартного отклонения роста (Standard Deviation Score - SDS). Для сравнения эффективности и оценки достоверности использовался непараметричский коэффициент Спирмана ( $<<0.05)$.

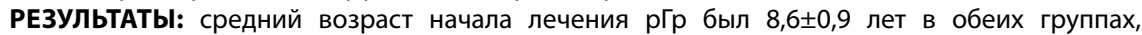
но в 1-й группе он составил $10,0 \pm 0,7$ лет, а во 2-й группе $-7,5 \pm 0,7$ лет ( $<<0,05)$. При этом средний SDS роста на момент начала лечения в 1-й группе составил $-2,5 \pm 0,3$, во 2-й группе $--2,8 \pm 0,3$ ( $>0,05)$, что дало возможность проведения сравнения результатов лечения. Средний возраст начала лечения эстрогеном в 1-й группе составил $11,4 \pm 0,8$ лет, костный возраст $-10,2+0,6$. При этом средний SDS роста перед началом лечения составил $-2,5 \pm 0,4$, а среднее увеличение SDS роста за 6 мес до назначения низких доз эстрогена было 0,08 \pm 0 . Среднее увеличение SDS роста за 6 мес среди пациенток 1-й группы составило 0,2 $\pm 0,0$, а среднее увеличение SDS роста за 6 мес среди пациенток 2-й группы - 0.035 $\pm 0,0$ ( $<<0,01)$.

Выводы: комбинированная терапия рекомбинантным гормоном роста с низкими дозами эстрогена достоверно больше увеличивает рост пациенток с синдромом Шерешевского-Тернера в сравнении с монотерапией, что позволяет говорить об улучшении социальной адаптации и качества жизни пациенток и их семей.

КЛЮЧЕВЫЕ СЛОВА: эндокринопатии у девочек, синдром Шерешевского-Тернера, гормон роста, эстрагены. 